\title{
ANALISIS PENGARUH COMMUNAL ACTIVATION TERHADAP KEPUTUSAN MEMBELI UNTUK MENINGKATKAN BRAND LOYALTY (STUDI KASUS TEH BOTOL SOSRO LESS SUGAR)
}

\author{
Annetta Gunawan \\ Management Department, School of Business Management, BINUS University \\ Jln. K. H. Syahdan No. 9, Palmerah, Jakarta Barat 11480 \\ annetta_gunawan@hotmail.com
}

\begin{abstract}
Established in 1974 PT Sinar Sosro is the first bottled ready-to-drink tea producer in Indonesia. In order to fulfill its lovers wherever they are, the newest innovation has been launched, i.e. Teh Botol Sosro Less Sugar, which focuses on diabetics, sportsmen/athletes, and young executives as its target markets. To foster brand loyalty and control the community, PT Sinar Sosro utilizes crowd combo marketing concept, especially communal activation activity that is adjusted with the current New Wave Marketing era, so PT Sinar Sosro can integrate supply and access of Teh Botol Sosro Less Sugar product. The objectives of this research are to analyze the influence of Communal Activation on Buying Decision of Teh Botol Sosro Less Sugar, and to analyze the influence of Communal Activation and Buying Decision on Brand Loyalty of Teh Botol Sosro Less Sugar. The data collection technique used was questionnaire disseminated to the members of Teh Botol Sosro Less Sugar online community, using Likert scale. While the data analysis technique used was Path Analysis. The result of Path Analysis shows the structural equation $Y=0,523 X+0,8526 \varepsilon_{1}$ which Communal Activation significantly contributes to Buying Decision at $27,3 \%$ and $Z=0,552 X_{2}+0,229 Y+0,7141 \varepsilon_{2}$ which Communal Activation and Buying Decision simultantly and significantly contribute to Brand Loyalty at $49 \%$.
\end{abstract}

Keywords: communal activation, buying decision, brand loyalty

\begin{abstract}
ABSTRAK
Berdiri pada 1974 PT Sinar Sosro merupakan perusahaan minuman teh siap minum dalam kemasan botol yang pertama di Indonesia. Untuk memenuhi kebutuhan pecintanya di mana pun mereka berada, inovasi terbaru Teh Botol Sosro Less Sugar telah diluncurkan dengan fokus target pasar penderita diabetes, olahragawan/atlet, dan eksekutif muda. Untuk memupuk brand loyalty dan mengendalikan komunitas tersebut, PT Sinar Sosro memanfaatkan konsep pemasaran crowd combo, khususnya kegiatan communal activation yang disesuaikan dengan era New Wave Marketing saat ini agar dapat mengintegrasikan penawaran dan akses untuk pemasaran produk Teh Botol Sosro Less Sugar. Tujuan dari penelitian ini antara lain adalah untuk menganalisis pengaruh Communal Activation terhadap Keputusan Membeli pada Teh Botol Sosro Less Sugar, serta untuk menganalisis pengaruh Communal Activation dan Keputusan Membeli terhadap Brand Loyalty pada Teh Botol Sosro Less Sugar. Adapun teknik pengumpulan data dengan kuesioner yang disebarkan kepada para anggota komunitas online Teh Botol Sosro Less Sugar menggunakan skala Likert; sedangkan teknik analisis data adalah Path Analysis. Hasil Path Analysis menunjukkan persamaan struktural $Y=0,523 X+0,8526 \varepsilon_{1}$ dengan Communal Activation berkontribusi signifikan terhadap Keputusan Membeli sebesar 27,3\% dan Z = $0,552 \mathrm{X}_{2}+0,229 Y+0,7141 \varepsilon_{2}$ dengan Communal Activation dan Keputusan Membeli secara simultan berkontribusi signifikan terhadap Brand Loyalty sebesar 49\%.
\end{abstract}

Kata kunci: communal activation, keputusan membeli, brand loyalty 


\section{PENDAHULUAN}

Walaupun Indonesia mendapat predikat sebagai negara produsen teh curah pada urutan ke lima di dunia setelah India, Cina, Sri Lanka, dan Kenya, sebagian besar produksi teh Indonesia (65\%) ditujukan untuk pasar ekspor (International Tea Committee, 2003). Hingga 2009, apresiasi konsumen domestik terhadap teh sebagai minuman kesehatan relatif masih rendah, yakni rata-rata baru 330 gram per kapita per tahun; amat jauh lebih rendah jika dibandingkan dengan konsumsi per kapita negaranegara produsen lainnya, seperti Sri Lanka 1.290 gram per kapita per tahun, Maroko 1.220 gram per kapita per tahun, India 660 gram per kapita per tahun, Irlandia 3.230 gram per kapita per tahun, dan Qatar 2.220 gram per kapita per tahun (Dinas Perkebunan Provinsi Jawa Barat, 2007). Salah satu penyebab rendahnya tingkat konsumsi teh dalam negeri adalah kurangnya edukasi pasar yang dilakukan dari berbagai pihak, baik itu dari pemerintah maupun perusahaan swasta dalam rangka memberikan informasi mengenai manfaat teh bagi kesehatan tubuh dalam jangka waktu yang panjang melalui perubahan gaya hidup masa kini (Admin, 2008). Oleh karena itu, perlu ditelusuri ulang taktik pemasaran dan bauran pemasaran yang digunakan oleh para pemain di industri minuman teh Indonesia. Tentunya dengan aplikasi rencana pemasaran yang matang di era yang tepat, akan mendukung eksistensi posisi perusahaan untuk menjadi top leader.

Pada era Pseudo Marketing ( $<1998)$ orang sudah belajar pemasaran namun tidak banyak yang menerapkannya dengan benar. Bagi mereka (konglomerat) yang berhubungan dekat dengan pemerintah akan lebih mudah ber-KKN yang semuanya serba vertikal (sentralisasi), termasuk bidang ekonomi. Lambat laun, banyak perusahaan baru sadar bahwa untuk bertahan dalam persaingan, mereka harus bisa lebih kompetitif khususnya setelah krisis Asia merajalela. Hal ini yang menyebabkan peralihan menuju era Legacy Marketing (1998-2008). Selanjutnya, kondisi pasar mendorong adanya perubahan marketing plan yang mengarah ke sistem desentralisasi (horizontal), yang di dalamnya customer menuntut layanan yang sama dari brand yang sama di mana pun mereka berada. Era ini disebut New Wave Marketing (>2008) yang masih berjalan hingga saat ini (Kartajaya, 2009). Pada era New Wave Marketing, konsep bauran pemasaran Product, Price, Place, Promotion (4P) bertransformasi menjadi Co-creation, Currency, Communal Activation, Conversation (4C) (Kartajaya, 2009). Penelitian ini membahas tentang implementasi Communal Activation yang pada PT Sinar Sosro.

PT Sinar Sosro sebagai pelopor minuman teh siap minum dalam kemasan (SMDK) pertama di Indonesia, meraih pangsa pasar mencapai $44,1 \%$ pada 2009 , masih di atas Coca Cola Group yang memperoleh pangsa pasar 26,2\%. Meskipun Teh Botol Sosro masih bercokol di klasemen market leader, PT Sinar Sosro tidak bisa tinggal diam begitu saja. Akibat adanya perubahan karakter konsumen di Indonesia yang makin kritis terhadap produk yang dikonsumsi dan juga makin teredukasi akan kepeduliannya terhadap tren global, yaitu hal-hal yang berkaitan dengan kualitas hidup, diluncurkanlah inovasi produk baru yakni Teh Botol Sosro Less Sugar.

Teh Botol Sosro Less Sugar yang berumur hampir 5 tahun ini, harus didampingi langkahlangkah strategis untuk meraih loyalitas pelanggan dengan merangkul mereka ke dalam sebuah komunitas. Kegiatan promosi yang telah dilakukan PT Sinar Sosro lewat iklan di media elektronik menandakan bahwa produk Teh Botol Sosro Less Sugar difokuskan bagi mereka yang berlatar belakang penderita diabetes, olahragawan/atlet, dan eksekutif muda. Untuk memupuk loyalitas dan mengendalikan komunitas tersebut, PT Sinar Sosro memanfaatkan konsep pemasaran crowd combo, yang disesuaikan dengan era New Wave Marketing saat ini. Hal ini dilakukan agar dapat mengintegrasikan penawaran dan akses untuk pemasaran produk Teh Botol Sosro Less Sugar.

Simamora (2004) memaparkan bahwa seorang pengambil keputusan sangat menentukan sebuah produk akan dibeli. Sesuai dengan prinsip ekonomi, seminimal mungkin pengorbanan yang dilakukan demi menjangkau produk yang diinginkan. Oleh karena itu, perusahaan harus lebih cekatan 
dalam menjemput bola dengan mengaktivasi komunitas merek produk yang dibutuhkan. Hal tersebut ingin mengatakan bahwa adanya hubungan kausalitas antara communal activation dengan keputusan membeli.

Masyarakat sebagai calon pelanggan mempunyai persepsi sendiri terhadap sebuah produk, dengan langkah selanjutnya mereka melakukan keputusan jika akan loyal terhadap produk itu atau tidak. Dalam hal ini, konsumen menjadi faktor penentu perusahaan mana yang berhasil menarik perhatian mereka. Salah satu tujuan dari pemasaran adalah untuk memperebutkan persepsi konsumen, bahwa persepsi konsumen dapat memengaruhi perilaku beli mereka (Prasetijo, 2005). Dengan kata lain, persepsi konsumen mampu meningkatkan persepsi keputusan membeli terhadap merek tersebut dan pada akhirnya memberikan kontribusi positif kepada perusahaan dengan memperkuat loyalitas pelanggan dalam sebuah komunitas yang terikat satu dengan lainnya. Bagi pihak manajerial, loyalitas pelanggan dalam sebuah komunitas tersebut merujuk pada Brand Loyalty Teh Botol Sosro Less Sugar.

Dari uraian tersebut, terdapat dua tujuan yang ingin dicapai dari penelitian ini. Tujuan pertama adalah untuk mengetahui dan menganalisis seberapa besar pengaruh Communal Activation terhadap Keputusan Membeli pada Teh Botol Sosro Less Sugar. Sedangkan tujuan kedua adalah untuk mengetahui dan menganalisis seberapa besar pengaruh Communal Activation dan Keputusan Membeli terhadap Brand Loyalty pada Teh Botol Sosro Less Sugar secara individual dan simultan.

Penelitian ini dilakukan dengan beberapa pembatasan masalah. Pertama-tama, praktik cocreation terhubung erat dengan currency yang lebih cenderung diimplementasikan pada kategori produk high involvement yang proses pembeliannya berlangsung lebih lama sebab konsumen harus memerhatikan dengan teliti setiap fitur dalam produk tersebut (Kartajaya \& Darwin, 2010). Sehingga kedua praktik tersebut tidak dapat diterapkan pada produk Teh Botol Sosro Less Sugar. Yang dimaksud dengan bauran pemasaran adalah crowd combo yang hanya difokuskan pada kegiatan communal activation yang nantinya akan berdampak pada conversation yang terjalin di dalam sebuah komunitas. Kemudian berhubungan dengan hal sebelumnya, yang kedua adalah target responden bukan semua pelanggan, melainkan member komunitas online produk Teh Botol Sosro Less Sugar.

\section{Tinjauan Literatur}

\section{Crowd Combo}

Seperti yang telah disinggung pada pendahuluan, dalam era New Wave Marketing saat ini konsep marketing mix berubah menjadi crowd combo, yang di dalamnya peranan individual sangat dominan. Oleh karena itu cakupan pasar akan lebih luas namun kata "crowd" berbeda dengan komunitas. Orang-orang dalam komunitas saling peduli serta memiliki ketertarikan dan nilai yang sama. Sementara "crowd" merupakan kumpulan individu yang lepas (Kartajaya, 2009). Kemudian kata "combo" berasal dari kata kombinasi (combination). Dengan demikian crowd combo terdiri dari sejumlah elemen, yaitu: Co-creation (sebagai pengganti Product), sifatnya cenderung lebih dinamis, interaktif, dan berasal dari multisumber; Currency (sebagai pengganti Price), yang maknanya lebih fleksibel dengan nilai tukarnya ditentukan oleh supply dan demand, spekulasi, kekuatan fundamental, asumsi-asumsi, dan intervensi; Communal Activation (pengganti Place), yang akan dibahas selanjutnya; Conversation (pengganti Promotion), yang bersifat dua arah, peer-to-peer, dan many-tomany, serta ditandai dengan adanya interaksi antarperusahaan dengan pelanggan dalam sebuah diskusi.

\section{Communal Activation}

Elemen ketiga dari marketing mix adalah place atau sering dikenal dengan marketing channel. Saluran distribusi inilah yang berperan dalam menghantarkan produk dari produsen ke pelanggan. 
Praktik channeling di dunia yang serba horizontal ini akan makin berubah menjadi ke arah komunal baik secara online maupun offline.

Komunitas adalah kumpulan manusia atau kelompok yang berkumpul dan berdiskusi karena memiliki tujuan atau ketertarikan yang sama dalam suatu bidang tertentu. Berbeda dengan terminologi organisasi yang ketat (strict) khususnya berhubungan dengan adanya tujuan tertentu yang dikejar bersama, komunitas relatif lebih bebas karena masing-masing individu bisa saja memiliki tujuan yang berbeda-beda. Sebuah komunitas itu tinggal di dunia nyata maupun dunia maya. Namun komunitas maya lebih fleksibel terutama dalam dimensi ruang dan waktu. Siapa pun, kapan pun, dan di mana pun berada, masih bisa tetap aktif bergabung dan berdiskusi dalam komunitas maya (Wahono, 2007). Justru dengan adanya komunitas, perusahaan harus jeli memanfaatkan peluang tersebut untuk memberi napas hidup pada komunitas yang menguntungkan.

Perusahaan seperti Facebook selaku komunitas jejaring sosial berbasis web merupakan salah satu contoh langkah pemasaran yang dilakukan lewat communal activation dapat terwujud. Populasi penggunanya sudah berjumlah kurang lebih 250 juta orang yang difasilitasi dengan berbagai aplikasi dan fitur yang menunjang kegiatan transaksi secara online.

Saluran distribusi pada zaman New Wave ini bukan lagi perusahaan distributor atau peritel namun berupa communal activation yang mampu mengaktifkan sebuah komunitas lewat para pemimpin atau aktivis komunitas tersebut. Dengan kata lain, produsen akan lebih efektif dan efisien jika berhasil dalam mengelola para aktivis yang lebih paham "bahasa" komunitas tersebut. Hal ini dikarenakan reputasi dan integritas sebagai pemimpin komunitas menjadi jaminan bagi anggota lainnya. Biaya yang diperlukan untuk mengelola para aktivis ini juga relatif tidak terlalu besar (Kartajaya, 2009).

Reputasi aktivis bicara tentang sosok pemimpin yang memiliki citra positif, bahwa pemimpin tersebut aktif mendorong pelaksanaan kegiatan dalam komunitas. Reputasi yang positif tidaklah cukup, diperlukan pula integritas dari aktivis tersebut. Integritas ditandai dengan kemampuan dalam menunjukkan kesinergian sehingga memiliki potensi yang memancarkan kejujuran, serta berpotensi aktif menunjukkan kesatuan yang utuh dalam organisasinya melalui berbagai kegiatan. Sedangkan efisiensi biaya ditandai dengan adanya biaya yang dikeluarkan perusahaan untuk mengurus kelangsungan hidup komunitas serta dukungan perusahaan terhadap kegiatan yang diselenggarakan komunitas berupa bantuan dana. Peran distributor yang digantikan oleh komunitas berupa akses terhadap informasi tentang produk terujud dengan adanya interaksi antarkomunitas. Interaksi ini juga terjadi ketika ada forum diskusi yang dibangun oleh pihak perusahaan dengan aktivis komunitas.

Maka dari itu, place is communal activation, tempat perusahaan berusaha mengaktifkan komunitasnya lewat connector yang ada di physical (offline) dan virtual (online). Jika sudah ada connector untuk komunitas, tentunya melakukan aktivitas pemasaran apa saja akan menjadi lebih mudah.

\section{Keputusan Membeli}

"Keputusan adalah penyeleksian dari pilihan-pilihan dua atau lebih alternatif," Schiffman dan Kanuk dalam Sumarwan (2004:289) mendefinisikan suatu keputusan adalah sebagai pemilihan suatu tindakan dari dua atau lebih pilihan alternatif. Seorang konsumen yang hendak melakukan pilihan, maka ia harus memilih pilihan alternatif. Jika konsumen tidak memilih pilihan alternatif, hal tersebut merupakan bukan situasi konsumen melakukan keputusan.

Proses kunci di dalam pembuatan keputusan konsumen adalah proses integrasi dengan mana pengetahuan dikombinasikan untuk mengevaluasi dua atau lebih alternatif perilaku, kemudian 
memilih salah satu. Hasil dari proses integrasi adalah suatu pilihan, secara kognitif terwakili sebagai intensi perilaku. Intensi perilaku disebut rencana keputusan (Limakrisna \& Supranto, 2007).

Kotler (2005:224) ada lima tahap dalam proses pembelian konsumen, yaitu: Pertama, pengenalan masalah, yaitu proses pembelian dimulai saat pembeli mengenali sebuah masalah atau kebutuhan. Kebutuhan tersebut dapat dicetuskan oleh rangsangan internal atau eksternal. Kedua, pencarian informasi, konsumen yang tergugah kebutuhannya akan terdorong untuk mencari informasi yang lebih banyak. Tantangan bagi marketer adalah mengenali sumber informasi yang paling berpengaruh. Ketiga, evaluasi alternatif, mengevaluasi berbagai alternatif yang ada dalam konteks kepercayaan utama tentang konsekuensi yang relevan dan mengombinasikan pengetahuan tersebut untuk membuat keputusan. Keempat, keputusan pembelian, calon pembeli menentukan apa dan di mana produk pilihan mereka yang akan dibeli. Marketer harus menyediakan jalan paling mudah bagi calon pembeli untuk mendapatkan produk yang mereka inginkan. Misalnya, produk sudah disalurkan hingga ke pengecer-pengecer kecil sehingga dapat menjangkau para calon pelanggan. Kelima, perilaku pascapembelian, hanya ada tiga kemungkinan, yaitu performa produk/jasa sama dengan ekspektasi, performa produk/jasa lebih rendah dari ekspektasi, dan performa produk/jasa lebih tinggi dari ekspektasi.

Tahap kedua dari proses pengambilan keputusan membeli menurut Kotler (2005), yakni mencari informasi sebanyak-banyaknya sebagai bentuk respons seorang konsumen untuk memenuhi kebutuhannya. Melalui communal activation komunikasi antaranggota komunitas mengenai ketertarikannya pada sebuah produk merupakan contoh konkret dari pencarian informasi. Selanjutnya tahap ke empat yaitu keputusan pembelian, calon pembeli menentukan tempat produk pilihan mereka akan dibeli. Kedua hal itu sekaligus menjadi tantangan bagi pemasar untuk lebih mengenali media atau sumber informasi yang paling berpengaruh, misalnya saja melalui situs jejaring sosial.

Hal serupa juga dilengkapi oleh Simamora (2004) yang memaparkan bahwa seorang pengambil keputusan sangat menentukan tempat sebuah produk akan dibeli. Dan sesuai dengan prinsip ekonomi, seminimal mungkin pengorbanan yang dilakukan demi menjangkau produk yang diinginkan. Oleh karena itu, perusahaan harus lebih cekatan dalam menjemput bola dengan mengaktivasi komunitas merek produk yang dibutuhkan. Beberapa hal tersebut ingin mengatakan bahwa ada hubungan antara communal activation dengan keputusan membeli.

\section{Brand Loyalty}

Menurut (Giddens \& Hofmann, 2002), "Brand loyalty adalah pilihan yang dilakukan konsumen untuk membeli merek tertentu dibandingkan merek yang lain dalam satu kategori produk." Sedangkan menurut Utama (2007), "Brand loyalty juga merupakan suatu pengukuran derajat di mana konsumen, mengakui suatu merek, yang dihasilkan dari kepuasan yang berkelanjutan dan adanya peningkatan dalam pembelian kembali suatu produk dengan sedikit pemikiran namun dengan keterlibatan yang tinggi." Brand loyalty terikat dengan laba masa depan karena secara langsung dihubungkan dengan tingkat penjualan masa depan. Pelanggan yang setia menunjukkan respons yang lebih menyenangkan terhadap suatu merek dibandingkan dengan pelanggan yang tidak loyal. Pelanggan yang setia terhadap sebuah merek akan melakukan pembelian secara rutin dan menolak untuk mengganti atau menukar dengan merek yang lain (Yoo \& Donthu, 2000).

Menurut Durianto, dkk. (2001:128), tingkatan-tingkatan yang terdapat dalam loyalitas merek adalah sebagai berikut. (1) Berpindah-pindah (switcher); pelanggan yang berada pada tingkat loyalitas ini dikatakan sebagai pelanggan yang berada pada tingkat yang paling dasar. Makin sering pembelian konsumen berpindah dari suatu merek ke merek yang lain mengindikasikan bahwa mereka tidak loyal; semua merek dianggap memadai. Dalam hal ini, merek memegang peranan kecil dalam keputusan pembelian. Ciri yang jelas dalam kategori ini adalah mereka membeli suatu merek karena harganya murah. (2) Pembeli yang bersifat kebiasaan (habitual buyer); pembeli pada tingkat ini dikategorikan 
sebagai pembeli yang puas dengan merek produk yang dikonsumsinya. Tidak ada alasan yang kuat baginya untuk membeli merek produk lain atau berpindah merek, terutama jika peralihan itu membutuhkan usaha, biaya, atau pengorbanan lain. Dapat disimpulkan bahwa pembeli ini membeli suatu merek karena kebiasaan. (3) Pembeli yang puas karena biaya peralihan (satisfied buyer); pada tingkatan ini, pembeli merek masuk ke kategori puas jika mereka mengonsumsi merek tersebut. (4) Menyukai merek (liking the brand); pembeli dalam kategori ini adalah pembeli yang benar-benar menyukai merek tersebut. Pada tingkat ini dijumpai perasaan emosional yang terkait dengan merek. Rasa suka pembeli ini bisa saja didasari oleh asosiasi yang terkait dengan simbol, rangkaian pengalaman dalam penggunaan sebelumnya baik yang dialami pribadi maupun kerabatnya ataupun yang disebabkan oleh karena persepsi kualitas yang tinggi. (5) Pembeli yang komit (comitted buyer); pada tahap ini pembeli merupakan pelanggan yang setia. Mereka memiliki suatu kebanggaan sebagai pengguna suatu merek dan bahkan merek tersebut menjadi sangat penting bagi mereka dipandang dari segi fungsinya maupun sebagai suatu ekspresi mengenai siapa mereka sebenarnya. Pada tingkatan ini, salah satu aktualisasi loyalitas pembeli ditunjukkan dengan tindakan merekomendasikan dan mempromosikan merek tersebut kepada pihak lain.

Tingkat keterikatan anggota komunitas sangat erat kaitanya dengan daya magnetik dari brand yang dikaguminya. Hal senada juga diyakini oleh Durianto, dkk. (2004), yang menyatakan bahwa salah satu peranan dan kegunaan merek adalah sebuah merek mampu menciptakan komunikasi interaksi dengan konsumen. Dengan kata lain, makin kokoh ikon itu berdiri, makin kokoh pula interaksi antara ikon dengan konsumen sehingga terbentuklah asosiasi merek yang memiliki kualitas dan kuantitas yang kuat di benak konsumen. Lanjut beliau, brand loyalty termasuk kategori ekuitas merek yang berperan meningkatkan penjualan karena bisa menciptakan loyalitas saluran distribusi (communal activation) bagi konsumen. Marconi (1993) juga menyebutkan hal yang senada, yaitu kenyamanan dan kemudahan untuk memperoleh merek merupakan salah satu faktor yang berpengaruh terhadap loyalitas merek. Situasi saat ini, permintaan pasar telah menyudutkan perusahaan untuk menyediakan produk dalam rangka memudahkan konsumen. Hal ini berarti bahwa terjadi hubungan antara communal activation dengan brand loyalty.

Tjiptono dan Chandra (2005) mengemukakan bahwa loyalitas merek adalah komitmen yang dipegang teguh untuk membeli ulang atau berlangganan dengan produk atau jasa yang disukai secara konsisten pada masa mendatang, sehingga menimbulkan pembelian merek yang sama secara berulang meskipun pengaruh situasional dan upaya pemasaran berpotensi menyebabkan perilaku beralih merek. Dengan demikian berarti bahwa brand loyalty mengakibatkan keputusan pembelian jika dijelaskan dalam teori Lau dan Lee (1999) dan teori yang dikemukakan Tjiptono dan Chandra (2005). Hal ini berarti bahwa terjadi hubungan antara brand loyalty dengan keputusan pembelian.

\section{METODE PENELITIAN}

Penelitian ini merupakan penelitian asosiatif. Populasi dalam penelitian ini merupakan member komunitas online Teh Botol Sosro Less Sugar di jejaring sosial facebook yang berjumlah 145 orang. Sedangkan jumlah sampel yang diambil berdasarkan rumus yang dikemukakan oleh Taro Yamane (Riduwan dan Kuncoro, 2007), sebanyak 107 responden. Dalam mengumpulkan data, penelitian ini menggunakan kuesioner dengan skala Likert untuk mengukur kelima variabel dengan diberikan bobot sebagai berikut: Nilai 1 = Sangat Setuju (SS); Nilai 2 = Setuju (S); Nilai 3 = Biasa (B); Nilai 4 = Tidak Setuju (TS); Nilai 5 = Sangat Tidak Setuju (STS). Variabel-variabel dalam penelitian ini dapat dioperasionalkan pada Tabel 1 berikut. 
Tabel 1 Operasionalisasi Variabel

\begin{tabular}{|c|c|c|c|}
\hline Variabel & Dimensi & Indikator & Skala \\
\hline \multirow[t]{8}{*}{$\begin{array}{l}\text { Communal } \\
\text { Activation (X) }\end{array}$} & \multirow[t]{2}{*}{ Reputasi Aktivis } & $\begin{array}{l}\text { Adanya orang yang aktif mendorong } \\
\text { pelaksanaan kegiatan dalam komunitas }\end{array}$ & Interval \\
\hline & & $\begin{array}{l}\text { Adanya pemimpin yang memiliki citra } \\
\text { positif }\end{array}$ & Interval \\
\hline & \multirow[t]{2}{*}{ Integritas Aktivis } & $\begin{array}{l}\text { Adanya orang yang mampu menunjukkan } \\
\text { kesinergian sehingga memiliki potensi yang } \\
\text { memancarkan kejujuran }\end{array}$ & Interval \\
\hline & & $\begin{array}{l}\text { Adanya orang berpotensi yang aktif } \\
\text { menunjukkan kesatuan yang utuh dalam } \\
\text { organisasinya melalui berbagai kegiatan }\end{array}$ & Interval \\
\hline & \multirow[t]{2}{*}{ Efisiensi Biaya } & $\begin{array}{l}\text { Biaya yang dikeluarkan perusahaan untuk } \\
\text { mengurus kelangsungan hidup komunitas }\end{array}$ & Interval \\
\hline & & $\begin{array}{l}\text { Perusahaan mendukung kegiatan yang } \\
\text { diselenggarakan komunitas berupa bantuan } \\
\text { dana }\end{array}$ & Interval \\
\hline & \multirow[t]{2}{*}{$\begin{array}{l}\text { Interaksi Antar } \\
\text { Komunitas }\end{array}$} & $\begin{array}{l}\text { Adanya forum diskusi yang dibangun oleh } \\
\text { pihak perusahaan dengan aktivis komunitas }\end{array}$ & Interval \\
\hline & & $\begin{array}{l}\text { Adanya kemampuan komunitas untuk } \\
\text { menggantikan peran distributor, dalam hal } \\
\text { akses terhadap informasi tentang produk }\end{array}$ & Interval \\
\hline \multirow[t]{9}{*}{$\begin{array}{l}\text { Keputusan } \\
\text { Membeli (Y) }\end{array}$} & \multirow[t]{2}{*}{$\begin{array}{l}\text { Pengenalan } \\
\text { Kebutuhan }\end{array}$} & $\begin{array}{l}\text { Timbul masalah atau kebutuhan akan } \\
\text { minuman teh dari calon konsumen }\end{array}$ & Interval \\
\hline & & $\begin{array}{l}\text { Merasa bahwa Teh Botol Sosro Less Sugar } \\
\text { sesuai dengan seleranya dalam } \\
\text { mengonsumsi minuman teh }\end{array}$ & Interval \\
\hline & \multirow[t]{2}{*}{$\begin{array}{l}\text { Pencarian } \\
\text { Informasi }\end{array}$} & $\begin{array}{l}\text { Mencari informasi sebelum memutuskan } \\
\text { untuk membeli }\end{array}$ & Interval \\
\hline & & $\begin{array}{l}\text { Mendengarkan saran teman atau media } \\
\text { elektronik untuk membeli }\end{array}$ & Interval \\
\hline & Evaluasi Alternatif & $\begin{array}{l}\text { Mempertimbangkan manfaat dan biaya } \\
\text { dalam menentukan produk teh }\end{array}$ & Interval \\
\hline & \multirow{2}{*}{$\begin{array}{l}\text { Keputusan } \\
\text { Membeli }\end{array}$} & Memutuskan produk untuk dikonsumsi & Interval \\
\hline & & $\begin{array}{l}\text { Membeli produk karena manfaat sesuai } \\
\text { kebutuhan }\end{array}$ & Interval \\
\hline & \multirow[t]{2}{*}{ Pasca Pembelian } & Perasaan setelah mengonsumsi produk & Interval \\
\hline & & $\begin{array}{l}\text { Reaksi atau respon setelah mengonsumsi } \\
\text { produk tersebut }\end{array}$ & Interval \\
\hline \multirow[t]{5}{*}{$\begin{array}{l}\text { Brand Loyalty } \\
\text { (Z) }\end{array}$} & Switcher & $\begin{array}{l}\text { Pembeli yang mengutamakan harga dalam } \\
\text { pembelian }\end{array}$ & Interval \\
\hline & Habitual Buyer & $\begin{array}{l}\text { Pembeli yang membeli merek karena } \\
\text { kebiasaan }\end{array}$ & Interval \\
\hline & Satisfied Buyer & $\begin{array}{l}\text { Pembeli yang puas dan bersedia } \\
\text { menanggung biaya peralihan }\end{array}$ & Interval \\
\hline & Liking The Brand & Pembeli yang sangat menyukai merek & Interval \\
\hline & Comitted Buyer & $\begin{array}{l}\text { Pembeli yang setia dan akan } \\
\text { merekomendasikan merek kepada orang lain }\end{array}$ & Interval \\
\hline
\end{tabular}


Hipotesis dalam penelitian ini adalah sebagai berikut.

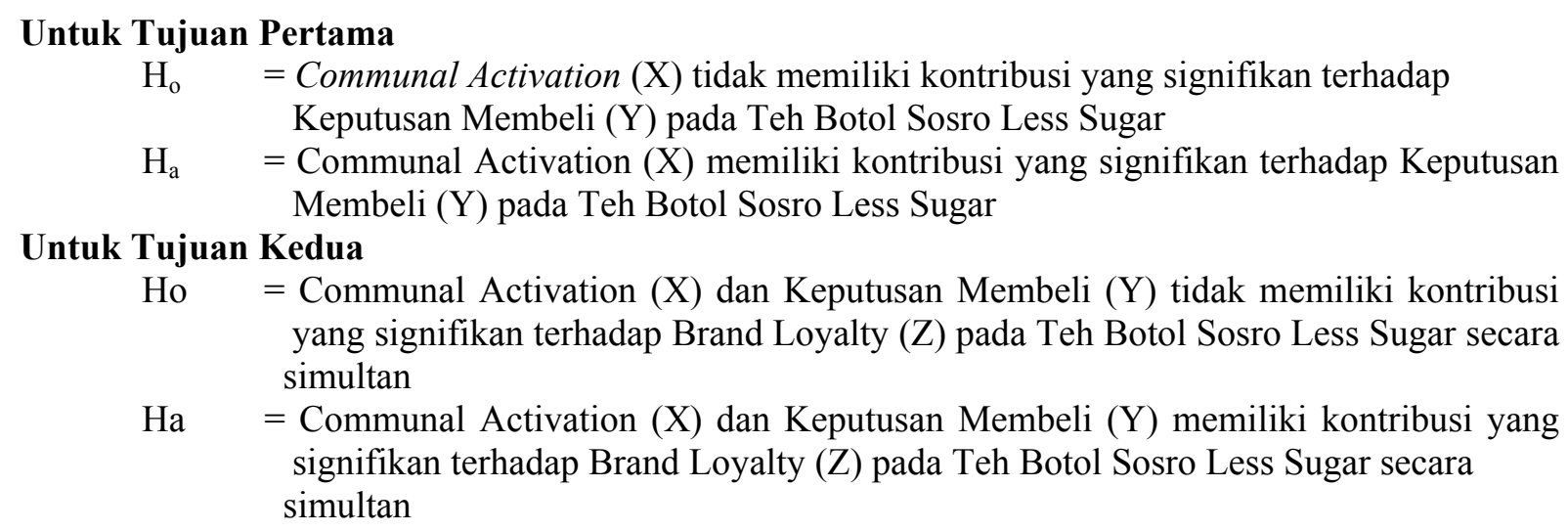

\section{HASIL DAN PEMBAHASAN}

Untuk menganalisis data digunakan beberapa teknik sesuai dengan prosedur dan pemasalahan penelitian, yaitu: Transformasi Data Ordinal menjadi Interval, Uji Validitas dan Reliabilitas, dan Uji Normalitas. Setelah itu baru dilakukan Analisis Jalur (Path Analysis) untuk menjawab tujuan penelitian.

\section{Uji Validitas-Reliabilitas dan Uji Normalitas}

Telah dilakukan uji validitas dan reliabilitas terhadap semua butir pernyataan, dan hasil akhir yang diperoleh adalah semua butir yang dimasukkan dalam perhitungan adalah valid dan reliabel. Dari hasil perhitungan SPSS, didapatkan bahwa kelima variabel dalam penelitian ini berdistribusi normal. Sehingga variabel X, Y, dan Z dapat digunakan dalam Analisis Jalur berikutnya.

\section{Analisis Jalur}

Rata-rata skor tiap dimensi dari masing-masing variabel disajikan pada Tabel 2 berikut.

Tabel 2 Rata-rata Variabel X, Y, dan Z

\begin{tabular}{llc}
\hline \multicolumn{1}{c}{ Variabel } & \multicolumn{1}{c}{ Dimensi } & Rata-rata \\
\hline Communal Activation & Reputasi Aktivis & 3,4567 \\
& Integritas Aktivis & 3,4664 \\
& Efisiensi Biaya & 3,4532 \\
& Interaksi Antar Komunitas & 3,5007 \\
\hline & Rata-rata Keseluruhan & $\mathbf{3 , 4 6 9 3}$ \\
\hline Keputusan Membeli & Pengenalan Kebutuhan & 4,1464 \\
& Pencarian Informasi & 4,0203 \\
& Evaluasi Alternatif & 3,9605 \\
& Keputusan Membeli & 4,0653 \\
& Pasca Pembelian & 3,9568 \\
\hline Brand Loyalty & Rata-rata Keseluruhan & $\mathbf{4 , 0 2 9 9}$ \\
\hline & Switcher & 3,1842 \\
& Habitual Buyer & 3,1208 \\
& Satisfied Buyer & 3,2211 \\
& Liking The Brand & 3,2766 \\
& Comitted Buyer & 3,3142 \\
\hline & Rata-rata Keseluruhan & $\mathbf{3 , 2 2 3 4}$ \\
\hline
\end{tabular}


Hasil korelasi bivariat antara variabel X, Y, dan Z dapat dilihat pada Tabel 3.

Tabel 3 Sifat Hubungan Bivariat X, Y, dan Z

\begin{tabular}{ccl}
\hline Hubungan antara & Korelasi & \multicolumn{1}{c}{ Sifat Hubungan } \\
\hline X dengan Y & 0,523 & Cukup Kuat, Searah, dan Signifikan \\
X dengan Z & 0,672 & Kuat, Searah, dan Signifikan \\
Y dengan Z & 0,518 & Cukup Kuat, Searah, dan Signifikan \\
\hline
\end{tabular}

Hasil dari analisis jalur substruktur 1 dapat dilihat pada Tabel 4 berikut.

Tabel 4 Rangkuman Hasil Koefisien Jalur Substruktur 1

\begin{tabular}{cccccc}
$\begin{array}{c}\text { Pengaruh Antar } \\
\text { Variabel }\end{array}$ & $\begin{array}{c}\text { Koefisien Jalur } \\
\text { (beta) }\end{array}$ & Nilai Sig & $\begin{array}{c}\text { Hasil } \\
\text { Pengujian }\end{array}$ & $\begin{array}{c}\text { Koefisien } \\
\text { Determinasi }\end{array}$ & $\begin{array}{c}\text { Koefisien } \\
\text { Variabel lain } \\
\left(\boldsymbol{\rho}_{\mathbf{y}} \boldsymbol{\varepsilon}_{\mathbf{1}}\right)\end{array}$ \\
\hline $\mathrm{X}_{1}$ terhadap Y & 0,523 & 0,000 & Ho ditolak & $0,273=27,3 \%$ & 0,8526 \\
\hline
\end{tabular}

Jadi dapat diperoleh persamaan stuktural substruktur 1:

$$
\begin{aligned}
& \mathrm{Y}=\rho_{\mathrm{YX}} \mathrm{X}+\rho_{\mathrm{y}} \varepsilon_{1} \\
& \mathrm{Y}=0,523 \mathrm{X}+0,8526 \varepsilon_{1} \text { dengan } \mathrm{R}^{2}=0,273
\end{aligned}
$$

Hipotesis pertama yang menyatakan "Communal Activation (X) memiliki kontribusi yang signifikan terhadap Keputusan Membeli (Y) pada Teh Botol Sosro Less Sugar", bahwa secara keseluruhan menyatakan signifikan. Besarnya kontribusi Communal Activation yang berpengaruh langsung terhadap Keputusan Membeli adalah 27,3\% dan sisanya sebesar 72,7\% dipengaruhi faktorfaktor lain di luar penelitian ini.

Communal Activation (X) berkontribusi secara positif dan signifikan terhadap Keputusan Membeli (Y) dengan sifat pengaruh 'sedang'. Communal Activation juga memiliki hubungan yang cukup kuat dengan Keputusan Membeli. Hal ini berarti makin efektif dan efisien Communal Activation yang diterapkan, maka tingkat Keputusan Membeli produk Teh Botol Sosro Less Sugar akan lebih tinggi. Oleh karena itu PT Sinar Sosro perlu mengembangkan aktivitas crowd combo, khususnya dalam elemen Communal Activation pada member komunitas online Teh Botol Sosro Less Sugar agar perilaku keputusan membeli yang dilakukan anggota tersebut juga meningkat.

Dari Tabel 2 diketahui bahwa rata-rata skor yang paling rendah dari keempat dimensi yang ada adalah dimensi efisiensi biaya. Hal ini menunjukkan biaya yang dikeluarkan oleh perusahaan demi mengelola komunitasnya masih terasa minim. Butir pernyataan yang memiliki total skor paling rendah adalah butir 5. Butir tersebut menyatakan bahwa opini responden mengenai perhatian perusahaan dalam mengurus kelangsungan hidup sebuah komunitas. Butir 6, yang menyatakan responden beranggapan tentang kesediaan perusahaan dalam mendukung acara yang diselenggarakan komunitasnya, memiliki total skor terendah kedua. Hal ini menunjukkan bahwa anggota komunitas online Teh Botol Sosro Less Sugar merasa masih kurang diperhatikan oleh perusahaan, salah satunya karena anggaran PT Sinar Sosro untuk mengelola kegiatan komunitasnya masih terbilang minim. Maka dari itu, PT. Sinar Sosro perlu mengalokasikan dana lebih untuk mempertahankan keberlangsungan hidup komunitasnya. Hal tersebut bisa dilakukan dengan merevisi kembali anggaran biaya promosi dan mengalokasikannya ke dalam aktivitas yang diselenggarakan para anggota komunitasnya. Dengan demikian hal tersebut menjadi lebih efisien dan tepat sasaran demi keuntungan pihak perusahaan. Contoh konkretnya, PT Sinar Sosro bisa menjadi donatur atau sponsorship dalam berbagai acara seminar atau penyuluhan yang bertemakan gaya hidup sehat, misalkan ditujukan bagi 
para anggota komunitas yang menderita penyakit diabetes. Atau juga memfasilitasi event komunitas olahraga yang sedang naik daun dengan memberikan produk Teh Botol Sosro Less Sugar dan seragam berlogo Teh Botol Sosro Less Sugar secara cuma-cuma kepada setiap anggota komunitas tersebut. Misalnya saja, gerak jalan dan folding bike (lebih sering disebut "seli") mengelilingi rute jalan protokol yang secara tidak langsung menjadi iklan berjalan karena biasanya diliput oleh para pemburu berita. Beberapa upaya tersebut ditujukan agar responden selaku target pasar dapat lebih merasakan kehadiran produk Teh Botol Sosro Less Sugar di tengah berjamurnya produk teh berkhasiat lainnya.

Dari hasil dari analisis jalur substruktur 2, didapatkan bahwa semua koefisien jalur signifikan sehingga tidak perlu dilakukan trimming, yang hasilnya dapat dapat dilihat pada Tabel 5 berikut ini.

Tabel 5 Rangkuman Model 2 Hasil Koefisien Jalur Substruktur 2

\begin{tabular}{cccccc}
\hline $\begin{array}{c}\text { Pengaruh Antar } \\
\text { Variabel }\end{array}$ & $\begin{array}{c}\text { Koefisien Jalur } \\
\text { (beta) }\end{array}$ & $\begin{array}{c}\text { Nilai } \\
\text { Sig }\end{array}$ & $\begin{array}{c}\text { Hasil } \\
\text { Pengujian }\end{array}$ & $\begin{array}{c}\text { Koefisien } \\
\text { Determinasi }\end{array}$ & $\begin{array}{c}\text { Koefisien Variabel lain } \\
\left(\boldsymbol{\rho}_{\mathbf{z}} \boldsymbol{\varepsilon}_{\mathbf{2}}\right)\end{array}$ \\
\hline X terhadap Z & 0,552 & 0,000 & Ho ditolak & $0,490=49 \%$ & 0,7141 \\
Y terhadap Z & 0,229 & 0,006 & Ho ditolak & $0,49 \%$ & 0,100 \\
\hline
\end{tabular}

Jadi dapat diperoleh persamaan stuktural dari Model 2 substruktur 2:

$$
\begin{aligned}
& Z=\rho_{z x} X+\rho_{z y} Y+\rho_{z} \varepsilon_{2} \\
& Z=0,552 X+0,229 Y+0,7141 \varepsilon_{2} \text { dengan } R^{2}=0,490
\end{aligned}
$$

Hipotesis kedua yang berbunyi "Communal Activation (X) dan Keputusan Membeli (Y) memiliki kontribusi yang signifikan terhadap Brand Loyalty (Z) pada Teh Botol Sosro Less Sugar secara simultan", bahwa secara keseluruhan menyatakan signifikan. Secara individual pun semua subvariabel diterima, karena berdasarkan pengujian jalur sub-struktur 2, koefisien jalur X terhadap Y dan koefisien jalur Y terhadap Z signifikan. Besarnya kontribusi Communal Activation yang berpengaruh langsung terhadap Brand Loyalty sebesar 0,552 $2^{2}$ x $100 \%=30,4 \%$ dan kontribusi Keputusan Membeli yang berpengaruh langsung terhadap Brand Loyalty sebesar $0,229^{2} \times 100 \%=5,2 \%$. Sedangkan besarnya kontribusi Communal Activation dan Keputusan Membeli secara simultan yang langsung mempengaruhi Brand Loyalty adalah 49\% dan sisanya sebesar 51\% dipengaruhi faktor-faktor lain di luar penelitian ini.

Communal Activation (X) berkontribusi secara positif dan signifikan terhadap Brand Loyalty (Z) dengan sifat pengaruh 'sedang'. Communal Activation juga memiliki hubungan yang kuat dengan Brand Loyalty. Hal ini berarti makin efektif dan efisien Communal Activation, maka makin tinggi juga Brand Loyalty merek Teh Botol Sosro Less Sugar. Berdasarkan hasil penelitian, Communal Activation diketahui memiliki pengaruh yang lebih besar terhadap Brand Loyalty ketimbang variabel Keputusan Membeli, dengan variabel Communal Activation memiliki koefisien beta paling besar. Oleh sebab itu, PT Sinar Soro perlu mengembangkan aktivitas crowd combo, khususnya dalam elemen Communal Activation pada member komunitas online Teh Botol Sosro Less Sugar agar meningkatkan Brand Loyalty produk yang bersangkutan. Tentunya hal ini didukung oleh pernyataan Durianto, dkk. (2001) mengenai rasa suka pembeli yang didasari oleh asosiasi yang terkait dengan ikon dan rangkaian pengalaman dalam penggunaan sebelumnya baik yang dialami pribadi maupun kerabatnya maupun yang disebabkan persepsi kualitas yang tinggi.

Dari Tabel 2 diketahui bahwa rata-rata skor yang paling rendah dari kelima dimensi yang ada adalah dimensi Habitual Buyer. Sedangkan kedua dimensi lainnya, yaitu Comitted Buyer dan Liking the Brand, menunjukkan total skor yang cukup tinggi. Hal ini menunjukkan bahwa para anggota komunitas online Teh Botol Sosro Less Sugar bukan tipikal pelanggan yang membeli karena kebiasaan. Komunitas itu termasuk golongan pelanggan yang membeli produk karena benar-benar 
menyukai merek tersebut hingga merekomendasikan orang lain untuk membeli Teh Botol Sosro Less Sugar. Dimensi Liking the Brand yang tinggi mungkin disebabkan oleh keterikatan rasa emosional yang kuat terhadap asosiasi merek Teh Botol Sosro Less Sugar. Sedangkan dimensi Comitted Buyer yang tinggi disebabkan karena timbulnya rasa kebanggaan tersendiri dan bahkan sebagai aktualisasi diri ketika mengonsumsi merek Teh Botol Sosro Less Sugar.

Hasil penelitian menunjukkan bahwa member komunitas online Teh Botol Sosro Less Sugar membeli produk bukan karena rutinitas belaka namun karena munculnya rasa emosional yang tinggi terhadap brand tersebut. Hal ini sejalan dengan pendapat Giddens (2002) bahwa para konsumen yang loyal dalam sebuah komunitas akan proaktif mengikuti informasi-informasi terbaru yang berkaitan dengan merek tersebut, bahkan bisa berperan serta sebagai juru bicara dari merek tersebut dan selalu mengembangkan hubungan interaksi dengan merek yang bersangkutan sehingga perusahaan dapat mengurangi biaya promosi produknya. Oleh karena itu, PT Sinar Sosro diharapkan mampu mempertahankan loyalitas merek di mata anggota komunitas online Teh Botol Sosro Less Sugar yang mayoritas masuk kategori committed buyer. Misalnya saja dengan mengaktivasi serta memberdayakan komunitas yang dimiliki baik secara virtual (online) maupun physical (offline) agar timbul kedekatan emosional melalui hubungan komunikasi secara horizontal antara merek tersebut dengan anggota dan juga sesama anggota komunitas.

Keputusan Membeli (Y) berkontribusi secara positif dan signifikan terhadap Efektivitas Organisasi ( $Z$ ) dengan sifat pengaruh 'lemah'. Keputusan Membeli juga memiliki hubungan yang cukup kuat dengan Brand Loyalty. Hal ini berarti makin tinggi Keputusan Membeli responden, maka akan tercapai Brand Loyalty yang tinggi pula. Maka dari itu, keputusan membeli merupakan salah satu faktor utama yang harus diperhatikan oleh PT Sinar Sosro untuk meraih brand loyalty merek Teh Botol Sosro Less Sugar. Oleh karenanya PT Sinar Sosro perlu mengkaji ulang taktik pemasaran yang dijalankan selama era New Wave ini, terutama pada elemen communal activation yang sering kali dipandang sebelah mata. Padahal hal itu bisa berdampak positif bagi perusahaan jika benar-benar dirancang sedemikian rupa sesuai era saat ini. Dengan mendekatkan diri secara intens lewat sebuah komunitas yang terjadi secara alamiah, perusahaan akan lebih sigap menanggapi keluhan yang tidak sesuai dengan harapan setelah membeli. Tak dipungkiri lagi bahwa komunitas online di Facebook yang keterikatan anggotanya tidak hanya kagum pada daya tarik magnetik dari ikon saja tetapi juga lebih bersifat stabil dan kuat karena hubungan antaranggota cukup erat (Kartajaya \& Darwin, 2010). Jika PT Sinar Sosro berhasil dalam mengelola hubungan dengan para aktivis di Facebook fanpage yang lebih membumi bahasanya dan sangat paham etikanya, sudah dipastikan taktik communal activation akan lebih mengena sasaran dan tepat guna.

\section{SIMPULAN}

Simpulan yang dapat diambil dari penelitian ini adalah sebagai berikut. Pertama, Communal Activation berkontribusi signifikan terhadap Keputusan Membeli sebesar 27,3\%. Kedua, Communal Activation dan Keputusan Membeli secara simultan berkontribusi signifikan terhadap Brand Loyalty sebesar 49\%. Sedangkan secara individual, Communal Activation berkontribusi langsung terhadap Brand Loyalty sebesar 30,4\% dan Keputusan Membeli juga berkontribusi langsung terhadap Brand Loyalty sebesar 5,2\%.

Saran yang diberikan dari hasil penelitian adalah sebagai berikut. Pertama, Sebaiknya PT Sinar Sosro lebih memfokuskan diri untuk menerapkan crowd combo, terutama elemen communal activation. Aktivitas communal activation yang bisa dilakukan adalah mengalokasikan dana promosi lebih diorientasikan untuk mempertahankan keberlangsungan hidup komunitasnya. Misalnya saja PT Sinar Sosro mengambil peranan sebagai donatur atau sponsorship dalam berbagai acara seminar atau 
penyuluhan yang berkaitan erat dengan tren global saat ini, yakni gaya hidup sehat dan juga pada event kopi darat lainnya, seperti berolahraga (senam pagi, gerak jalan, bersepeda) bersama. Kedua, sebaiknya PT Sinar Sosro melakukan aktivasi beragam media virtual (online) yang sudah ada, seperti facebook, twitter, detikforum, koprol, dan sebagainya, sehingga muncul keterikatan emosional antara para anggota komunitas dengan ikon (merek produk Teh Botol Sosro Less Sugar) juga antarsesama anggota komunitas yang berhubungan secara horizontal. Hal demikian dimaksudkan agar penggemar Teh Botol Sosro Less Sugar yang haus akan informasi mengenai ikonnya dapat selalu meng-update kegiatan yang sedang atau akan dilakukan perusahaan terhadap merek produk yang mereka cintai. Tak bisa dipungkiri, kegiatan aktivasi secara online juga harus diselimuti dengan mengaktifkan komunitasnya lewat aktivis komunitas tersebut selaku connector yang ada di physical (offline). Jika perusahaan sudah mampu merangkul connector untuk komunitas tertentu, tentunya dalam melakukan aktivitas pemasaran apa saja akan lebih mudah sekaligus akan meningkatkan daya beli pelanggan. Ketiga, sebaiknya PT Sinar Sosro mengidentifikasi terlebih dahulu jaringan komunitas mana yang berpotensial untuk mendukung kegiatan communal activation pada merek produk Teh Botol Sosro Less Sugar. Setelah itu, perusahaan menelusuri lebih lanjut siapa di balik layar yang memegang kendali komunitas tersebut. Dan selanjutnya perusahaan memantau segala macam aktivitas yang sudah dan akan dilakukan oleh para anggota komunitas tersebut. Tiga langkah sederhana saran tersebut ditujukan supaya perusahaan pun mengetahui latar belakang (asal muasal) berdirinya komunitas tersebut dan letak fase komunitas itu sedang berjalan. Kemudian diharapkan ada perwakilan perusahaan yang mampu menggaet dan membina hubungan dengan connector yang tergabung dalam komunitas tersebut. Melalui adanya komunitas yang loyal ini, pemasar diberikan kemudahan untuk menjaga serta menjalin keharmonisan hubungan dua arah yang menunjang mereka (para anggota komunitas secara online atau offline) secara aktif ikut serta memberikan aspirasi atau suara perwakilan dalam merancang secara konseptual dan menghasilkan produk-produk yang inovatif sesuai dengan keinginan dan kebutuhan pasar.

\section{DAFTAR PUSTAKA}

Admin. (2008). Komoditi Teh Indonesia. Diakses 15 Januari 2010 dari http://www.csrreviewonline.com.

Dinas Perkebunan Provinsi Jawa Barat. (2007). Tea Festival. Diakses 3 September 2009 dari http://www.disbun.jabarprov.go.id.

Durianto, D., Sugiarto, dan Sitinjak, T. (2001). Strategi Menaklukan Pasar melalui Riset Ekuitas dan Perilaku Konsumen. Jakarta: Gramedia.

Giddens, N., and Hofmann, A. (2002). Brand Loyalty. Diakses 21 Desember 2009 dari http://www.extension.iastate.edu.

International Tea Committee (ITC). (2003). Annual Bulletin of Statistics 2003. London: International Tea Committee.

Kartajaya, H. (2009). New Wave Marketing. Jakarta: Gramedia Pustaka Utama.

Kartajaya, H., dan Darwin, W. (2010). Connect!. Jakarta: Gramedia Pustaka Utama.

Kotler, P. (2005). Manajemen Pemasaran. Edisi Kesebelas. Jilid 1. Jakarta: Indeks Kelompok Gramedia. 
Lau, G. T., and Lee, S. H. (1999). Customer's Trust in a Brand and the Link to Loyalty. Journal of Market Focussed Management, 4.

Limakrisna, N., dan Supranto, J. (2007). Perilaku Konsumen dan Strategi Pemasaran. Mitra Wacana Media, Jakarta.

Marconi, J. (1993). Beyond Branding. Chicago: Probus Publishing Company, Chicago.

Prasetijo, R. (2005). Perilaku Konsumen. Jakarta: Andi.

Riduwan dan Kuncoro, E. A. (2007). Cara Menggunakan dan Memaknai Analisis Jalur (Path Analysis). Bandung: Alfabeta.

Simamora, B. (2004). Riset Pemasaran. Jakarta: Gramedia Pustaka Utama.

Sumarwan, U. (2004). Perilaku Konsumen: Teori dan Penerapannya dalam Pemasaran. Bogor: Ghalia Indonesia.

Tjiptono, F., dan Chandra, G. (2005). Service, Quality, and Satisfaction. Jakarta: Andi.

Utama, D. B. (2007). Brand Loyalty. Jurnal Telaah Manajemen. Vol. 2 No. 2, November 2007.

Wahono, R. S. (2007). 6 Tahap Membangun Komunitas Maya. Diakses 10 Mei 2010 dari http://romisatriawahono.net.

Yoo, B., and Donthu, N. (2000). Testing Cross-Cultural Invariance of the Brand Equity Creation Process. Journal of Product \& Brand Management. Vol. 11 No.6, 2002. 